\title{
Influence of Drying Temperature on Tensile and Bursting Strength of Bacterial Cellulose Biofilm
}

\author{
Florentina SEDERAVIČIŪTE் 1 *, Jurgita DOMSKIENE் ${ }^{1}$, Ilze BALTINA ${ }^{2}$ \\ ${ }^{1}$ Kaunas University of Technology, Faculty of Mechanical Engineering and Design, Studentu st. 56, LT - 51424, Kaunas, \\ Lithuania \\ ${ }^{2}$ Riga Technical University, Faculty of Material Sciences and Applied Chemistry, Kipsalas iela 6-222. Riga, LV - 1658, \\ Latvia \\ cross $^{\text {ref }}$ http://dx.doi.org/10.5755/j01.ms.25.3.20764
}

Received 08 May 2018; accepted 12 September 2018

\begin{abstract}
The article presents an experimental study of mechanical properties of cellulose biofilm produced by bacterial fermentation process. Naturally derived biomaterial has great current and potential applications therefore the conditions of material preparation as well as control and prediction of mechanical properties is still a relevant issue. Bacterial cellulose was obtained as a secondary product from Kombucha drink. Presented technique for material preparation and drying is particularly simple and easy to access. The influence of drying temperature $\left(25^{\circ} \mathrm{C}, 50{ }^{\circ} \mathrm{C}\right.$ and $\left.75^{\circ} \mathrm{C}\right)$ on the sample size (thickness and planar dimensions) and mechanical properties (tensile and bursting strength) of cellulose biofilm has been evaluated. It was estimated that during drying biofilm specimens lost up to $92 \%$ of weight and up to $87 \%$ of thickness therefore planar specimen dimensions varied insignificantly. The study showed that the drying temperature is important for optimum strength properties of bacterial cellulose biofilm. The maximum tensile strength $\left(27.91 \mathrm{MPa}\right.$ ) was recorded for the samples dried at temperature of $25^{\circ} \mathrm{C}$, when the moisture from the biomaterial is removed gradually and good deformation properties are ensured (respectively tensile extension $18.8 \%$ ). Under higher drying temperature biomaterial shows lower values of tensile strength and higher values of bursting strength. The maximum bursting strength $(57.2 \mathrm{MPa})$ was recorded for samples dried at $75{ }^{\circ} \mathrm{C}$ when punch displacement changes were insignificant for all tested samples (from $17.8 \mathrm{~mm}$ to $21.7 \mathrm{~mm}$ ).
\end{abstract}

Keywords: bacterial cellulose, drying temperature, mechanical properties, tensile test, bursting strength.

\section{INTRODUCTION}

Cellulose is the most abundant organic compound on Earth. This material is associated with plants, but certain type of bacteria can also produce it. Bacterial cellulose (BC) has unique structure and properties. It can be synthesized by bacteria Gluconacetobacter xylinus, which is found in fruits, vegetables, vinegar, fruit juices and alcoholic beverages [1].

Bacterial cellulose has porous structure of threedimensional network of fibrils. These fibrils are around $100 \mathrm{~nm}$ in diameter and are composed of much finer nanofibrils of 2-4 $\mathrm{nm}$ in diameter [2].

Bacterial cellulose has great current and potential applications in food [3], medicine [4], electronics [5], nanocomposite industries [6], because of properties such as a high degree of purity, polymerization, crystallinity, tensile strength, water absorption, water retaining capacity, biological adaptability, biocompatibility, biodegradability and renewability.

Kombucha film as by-product of fermented sweetened tea [7] could be used as additional source of bacterial cellulose. An origin of China, Kombucha is composed of yeast and acetic acid bacteria, which forms a cellulose film. Kombucha drink is popular in many countries and many benefits of consuming this drink have been reported [8]. Some research found where purification process and

\footnotetext{
* Corresponding author. Tel.: +37068502685.

E-mail address: florentina.sederaviciute@ktu.edu (F. Sederaviciute)
}

structure of bacterial cellulose obtained from Kombucha was investigated $[9,10]$.

Cellulose sheet is produced with the help of bacterial fermentation process, when the gel like biofilm floats on the liquid medium surface. Stable and solid film is obtained when wet membrane is dried. The biomaterial of bacterial cellulose is highly hydrophilic, therefore drying procedure is important in order to obtain certain material [11].

The significant factors that many researchers have proved as drying method, temperature and time, growing media and conditions, duration of growth, bacteria, carbon and nitrogen source can have an influence on mechanical properties of BC biofilm [12, 13, 14].

The research was conducted to identify suitable drying method to produce dry cellulose using three methods: freeze drying, spray drying, supercritical drying and oven drying as control method [15]. Spray drying was proposed as a technically suitable manufacturing process to dry cellulose nanofibrils. Other research [16] proved that using a tray dryer and changing temperature from $40{ }^{\circ} \mathrm{C}$ to $110^{\circ} \mathrm{C}$ the moisture is effectively removed at $60^{\circ} \mathrm{C}$ and higher drying temperatures.

The morphology test, swelling measurement, crystallinity and tensile strength investigations were performed for the biofilm samples that were dried using three physical drying methods such as oven, tray dryer or freeze-drying until samples reached 3-5\% moisture content. Different drying method gave different properties 
of biomaterial and freeze-dried sample showed the highest tensile strength up to $148 \mathrm{MPa}$ [17].

Tensile strength properties were investigated for $\mathrm{BC}$ biofilm, which was dried in a room, oven at $60{ }^{\circ} \mathrm{C}$, and dried by lyophilizer with rising temperature from $20^{\circ} \mathrm{C}$ to $50{ }^{\circ} \mathrm{C}$. The best tensile strength properties were obtained for samples dried at $60{ }^{\circ} \mathrm{C}$ [18].

Scientist M. Zeng with his colleagues obtained BC from two bacterial strains (Gluconacetobacter Xylinus (GX) and Gluconacetobacter Europaeus) and used three biofilm drying methods: solvent evaporation at the room temperature, freeze drying and supercritical drying [19]. It was concluded that drying method modifies the porosity, mechanical properties and water absorption capability of the BC films. The best mechanical properties for Gluconacetobacter Xylinus were obtained when material was dried at the room temperature.

Wet BC sheets of the same origin Gluconacetobacter Xylinus were freeze dried, dried at room temperature $\left(25^{\circ} \mathrm{C}\right)$ and dried at elevated temperature $\left(50^{\circ} \mathrm{C}\right)$ by M.UlIslam et al. [20]. It was shown that increasing temperature to a certain point has a positive effect on the mechanical properties of $\mathrm{BC}$ and the highest stress values (around $40 \mathrm{MPa}$ ) were obtained for samples dried at $50{ }^{\circ} \mathrm{C}$.

Mostly known scientific researches of bacterial cellulose are based on the investigation of material obtained by standardized bacteria and growing media. Researchers use different techniques to prepare and treat bacterial cellulose. Generally, $\mathrm{NaOH}$ of variuos concentrations is used to purify BC film [21]. The growing interest for naturally fermentated biomaterial as the source of bacterial cellulose and problems concerning material treatment and mechanical properties is a relevant issue that should be explored.

Bacterial cellulose biofilm as a secondary product of fermented Kombucha drink was investigated in this study. The aim of the research is to estimate the influence of oven drying temperature on the mechanical properties of dried $\mathrm{BC}$ biofilm - tensile and biaxial strength as well as deformation. The information of biomaterial's mechanical behaviour is important to predict the quality of the final product. The limits of biaxial tension may be valuabale for the evaluation of processing smooth three-dimensional shape.

\section{EXPERIMENTAL DETAILS}

Preparation of biofilms. In this study the biofilm of bacterial cellulose (BC) was produced using Kombucha strains primary referred as the gram-negative bacteria species Gluconacetobacter xylinus (formerly Acetobacter xylinum). Culture medium prepared of $1 \mathrm{~L}$ water, $4 \mathrm{~g}$ green tea, $100 \mathrm{~g}$ of sucrose and $100 \mathrm{~mL}$ of $6 \%$ yeast extract. The prepared medium was incubated with Kombucha strain and fermentation was carried out under standard room conditions $\left(20 \pm 2{ }^{\circ} \mathrm{C}\right.$ temperature and $65 \pm 5 \%$ relative air humidity) for 7 days in static cultivation conditions.

Drying. During Kombucha strain fermentation, floating on medium surface gel-like biofilm was produced. Removed film was washed several times with distilled water and squeezed to reduce its water content. The samples were covered with tissue paper to protect the film surface.
Washed film samples were dried on the horizontal surface in the laboratory oven SNOL $60 / 300 \mathrm{LFN}$ at $25 \pm 1^{\circ} \mathrm{C}$ (sample code $\mathrm{BC} 25$ ), $50 \pm 1^{\circ} \mathrm{C}$ (sample code $\mathrm{BC} 50$ ) and $75 \pm 1{ }^{\circ} \mathrm{C}$ (sample code BC75) until it gained a constant specimen weight. Dried biofilm samples were used for the thickness, shrinkage and mechanical behaviour investigations.

Size parameters of BC. Thickness of each BC specimen was measured by a digital indicator DPT 60 with accuracy of $0.01 \mathrm{~mm}$. The average value of 5 measurements was calculated for the investigations. The thickness was estimated from wet and dry material at each 1 hour step during drying process. The percentage thickness loss was calculated.

The shrinkage of biofilm was determined by measuring size of BC specimen with accuracy of $0.5 \mathrm{~mm}$. For each drying procedure, the diameter of biofilm specimen was determined before and after drying and the percentage diameter loss was calculated.

Hardness measurements. The hardness of dried biofilm was measured by Durometer. Durometer hardness testing was performed using the Shore A scale. Shore hardness was used as an indication of biofilm stiffness.

Tensile strength. The tensile properties of dried BC samples were investigated by TINIUS OLSEN H10 KT tensile test machine according to ISO 3376:2011 standard [22]. Samples were cut with a standard pick form: overall length $-110 \mathrm{~mm}$, initial distance between grips $-50 \mathrm{~mm}$, width of narrow parallel-sided portion $-10 \mathrm{~mm}$. The crosshead rate of $100 \mathrm{~mm} / \mathrm{min}$ was set. To estimate the average result 7 specimens have been tested. The loadextension curve was recorded to determine tensile strength, tensile modulus and extension at break.

Bursting strength. The ball burst test was carried out with Instron tensile testing machine equipped with the original test unit (Fig. 1) according to ISO 9073-5:2008 standard [23].

Disc-shaped specimens (specimen diameter $70 \mathrm{~mm}$, internal clamp diameter $44.5 \mathrm{~mm}$ ) were loaded by steel spherical punch (diameter $25.4 \mathrm{~mm}$ ) up to rupture. Deformation rate was set $50 \mathrm{~mm} / \mathrm{min}$. Punch displacement (distance travelled by the plunger until specimen burst) and bursting load was estimated and the curve of whole sample deformation process was recorded.

\section{RESULTS}

\subsection{The influence of drying on size parameters and hardness}

The BC biofilm is extremely hydrophilic and drying characteristics demonstrate how efficiently moisture can be removed. The parameters of thickness loss and weight loss indicate the removal of water content in drying process. The dynamic of curves and its thickness loss showed (Fig. 2) different drying rate for each drying temperature. At higher temperature moisture is removed more effectively and drying process takes less time. A maximum weight loss (Table 1) of $91.8 \%$ was determined for the samples dried at $50{ }^{\circ} \mathrm{C}$ and $88.3 \%$ was estimated for the samples dried at $75{ }^{\circ} \mathrm{C}$, and $85.5 \%$-for the samples dried at $25{ }^{\circ} \mathrm{C}$ temperature. In the study the water content of the 
obtained bacterial cellulose film from Kombucha was up to $92 \%$ when other researchers got results of 90-95\% [24]. Drying process at $50{ }^{\circ} \mathrm{C}$ until constant sample weight was observed to be $70 \%$ shorter and drying at $75{ }^{\circ} \mathrm{C}$ was $58 \%$ shorter than drying at $25^{\circ} \mathrm{C}$ temperature process, which was running approximately 27 hours.

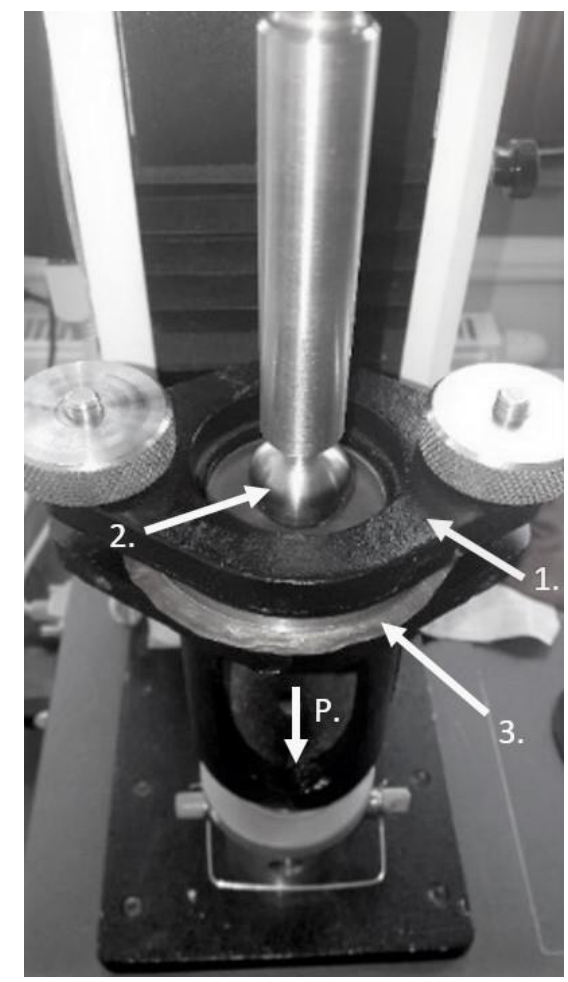

Fig. 1. Original ball burst test unit: 1-upper clamp; 2-punch; 3 -biofilm specimen; $\mathrm{P}$-bursting load direction

Table 1. Drying properties of BC

\begin{tabular}{|c|c|c|c|}
\hline & BC25 & BC50 & BC75 \\
\hline Drying temperature, ${ }^{\circ} \mathrm{C}$ & $25 \pm 1$ & $50 \pm 1$ & $75 \pm 1$ \\
\hline $\begin{array}{l}\text { Density of wet sample, } \mathrm{g} / \mathrm{m}^{3} \\
\left(\mathrm{CV}, \%^{*}\right)\end{array}$ & $\begin{array}{l}1411 \\
(6.4) \\
\end{array}$ & $\begin{array}{r}789 \\
(5.8) \\
\end{array}$ & $\begin{array}{c}722 \\
(5.2) \\
\end{array}$ \\
\hline $\begin{array}{l}\text { Density of dry sample, } \mathrm{g} / \mathrm{m}^{3} \\
\left(\mathrm{CV}, \%^{*}\right)\end{array}$ & $\begin{array}{l}204.6 \\
(2.6) \\
\end{array}$ & $\begin{array}{l}64.7 \\
(1.9) \\
\end{array}$ & $\begin{array}{l}84.5 \\
(4.9) \\
\end{array}$ \\
\hline Weight loss, $\%$ & 85.5 & 91.8 & 88.3 \\
\hline $\begin{array}{l}\text { Thickness of dry sample, } \mathrm{mm} \\
(\mathrm{CV}, \% *)\end{array}$ & $\begin{array}{l}0.36 \\
(2.3)\end{array}$ & $\begin{array}{l}0.47 \\
(3.1)\end{array}$ & $\begin{array}{l}0.63 \\
(4.6)\end{array}$ \\
\hline $\begin{array}{l}\text { Thickness of wet sample, } \mathrm{mm} \\
\left(\mathrm{CV}, \%^{*}\right)\end{array}$ & $\begin{array}{l}0.43 \\
(8.9)\end{array}$ & $\begin{array}{l}0.53 \\
(5.7)\end{array}$ & $\begin{array}{l}0.79 \\
(7.8) \\
\end{array}$ \\
\hline Thickness loss, $\%$ & 83.9 & 88.6 & 79.6 \\
\hline $\begin{array}{l}\text { Diameter of dry sample, } \mathrm{mm} \\
\left(\mathrm{CV}, \%^{*}\right)\end{array}$ & $\begin{array}{l}13.9 \\
(3.6) \\
\end{array}$ & $\begin{array}{l}17.6 \\
(4.9) \\
\end{array}$ & $\begin{array}{l}15.3 \\
(2.5) \\
\end{array}$ \\
\hline $\begin{array}{l}\text { Diameter of wet sample, } \mathrm{mm} \\
\left(\mathrm{CV}, \%^{*}\right)\end{array}$ & $\begin{array}{l}14.6 \\
(5.2) \\
\end{array}$ & $\begin{array}{l}17.7 \\
(4.6) \\
\end{array}$ & $\begin{array}{l}15.4 \\
(3.4) \\
\end{array}$ \\
\hline Diameter loss, $\%$ & 0.04 & 0.005 & 0.003 \\
\hline $\begin{array}{l}\text { Shore hardness } \\
(\mathrm{CV}, \% *)\end{array}$ & $\begin{array}{c}41 \\
(10.1)\end{array}$ & $\begin{array}{c}46 \\
(12.8)\end{array}$ & $\begin{array}{c}61 \\
(10.5) \\
\end{array}$ \\
\hline
\end{tabular}

It's evident that heat applied during drying process has influence on the size parameters of BC sample and the most significant changes are recorded for the thickness and weight loss therefore planar dimensions vary insignificantly. Some physical appearance changes of biofilm were captured also (Fig. 3). The surface of the dried BC sample shrunk more at higher drying temperature. This is confirmed by the recording of higher sample thickness values as well. The surface shrinkage might appear due to more rapid water evaporation at higher drying temperature that as was described in research [25] causes a closer contact between nanofibers and agglomeration.

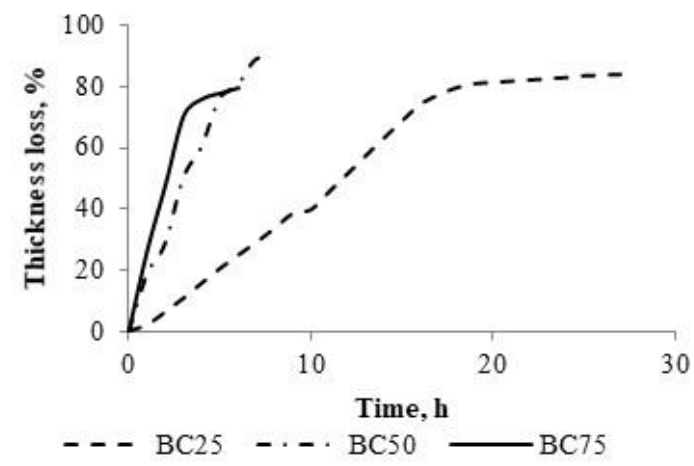

Fig. 2. The dependence of the thickness loss of BC samples during drying

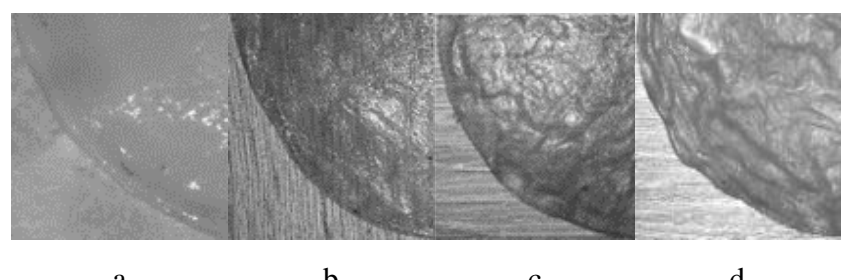

a

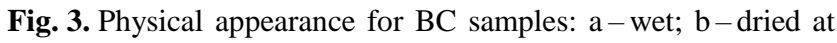
$25^{\circ} \mathrm{C}$; c-dried at $50^{\circ} \mathrm{C}$, d-dried at $75^{\circ} \mathrm{C}$

Change of biomaterial hardness was estimated - BC material dried at lower temperature obtains more soft structure (Shore A value 41 for BC25) as samples dried at higher temperatures derive medium soft (Shore A value 46 for BC50) and medium hard (Shore A value 61 for BC75) nature.

\subsection{The influence of drying on tensile properties}

Mechanical properties are the key parameters of biofilm to be useful for industrial purpose. The results of tensile test proved that drying procedure has strong influence on the strength properties of biomaterial. Experiment confirmed that wet biomaterial is elastic (the highest extension value of $35.1 \%$ and lowest $E$ modulus obtained for gel-like sample BCwet) but strength is low $(\sigma=0.4 \mathrm{MPa})$ (Table. 2).

Table 2. Tensile properties of BC biofilms

\begin{tabular}{|l|c|c|c|c|}
\hline & BCwet & BC 25 & BC 50 & BC 75 \\
\hline Maximum force $F, \mathrm{~N}$ & 14.7 & 100.5 & 81.2 & 65.6 \\
$(\mathrm{CV}, \% *)$ & $(3.1)$ & $(3.1)$ & $(5.9)$ & $(19.9)$ \\
\hline Tensile strength $\sigma, \mathrm{MPa}$ & 0.4 & 27.9 & 17.3 & 12.8 \\
\hline Extension $\varepsilon, \%$ & $35.1(15.9)$ & 18.8 & 20.1 & 4.5 \\
$(\mathrm{CV}, \% *)$ & $(12.5)$ & $(19.1)$ & $(4.3)$ \\
\hline Tensile modulus $E, \mathrm{MPa}$ & 0.02 & 2.78 & 1.83 & 2.65 \\
\hline * CV indicate result's variation
\end{tabular}


Dried biomaterial obtains different tensile behaviour higher tensile strength but lower extension (Fig. 4). The highest breaking strength value $(\sigma=27.91 \mathrm{MPa})$ was observed for samples dried at $25{ }^{\circ} \mathrm{C}$, consequently the worst tensile properties were observed for the $\mathrm{BC}$ samples dried at $75^{\circ} \mathrm{C}$ - the lowest values of breaking strength $(\sigma=12.8 \mathrm{MPa})$ and extension $(4.5 \%)$ were recorded.

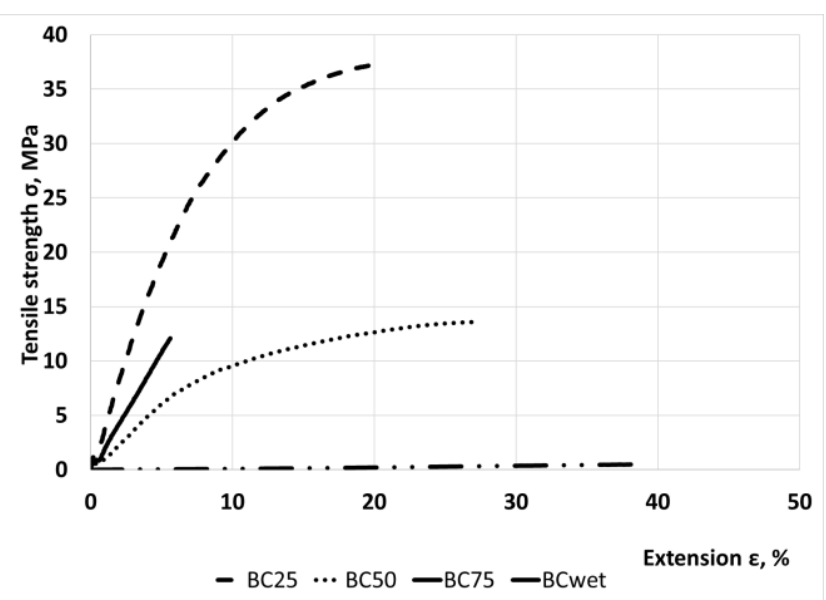

Fig. 4. Typical tensile strength - extension curves obtained for the BC samples

Tensile extension values obtained similar for the samples dried at $25{ }^{\circ} \mathrm{C}$ and $50{ }^{\circ} \mathrm{C}$ - respectively $18.8 \%$ and $20.1 \%$. It shows that dried at a higher temperature material loses its strength therefore ability to deform does not change. Breaking strength values for samples dried at $50{ }^{\circ} \mathrm{C}$ were $38 \%$ lower than for the samples dried at $25^{\circ} \mathrm{C}$. Dried samples acquired more stiff structure and increase of tensile modulus $\mathrm{E}$ was estimated. Tensile modulus for gel like BCwet sample is $0.02 \mathrm{MPa}$, as samples dried at $25^{\circ} \mathrm{C}$ and $75^{\circ} \mathrm{C}$ make much higher and similar modulus $\mathrm{E}$ (respectively $2.78 \mathrm{MPa}$ and $2.65 \mathrm{MPa}$ ) and a lower value for sample $\mathrm{BC} 50$ is recorded $-1.83 \mathrm{MPa}$.

The results proved that $\mathrm{BC}$ samples are sensitive to drying temperature and under higher temperature biomaterial obtains more stiff structure. Lower drying temperatures help to preserve the porous structure, strength and deformation properties of material.

Comparing obtained results with other researches $[15,24,25]$ it was confirmed that strong and resilient to mechanical impact dry bacterial cellulose biomaterial can be produced from Kombucha.

The high scattering of elongation result (up to $19.1 \%$ ) demonstrates the non-uniform structure of bacterial cellulose. The $\mathrm{BC}$ material is produced during natural fermentation process which strongly depends on many parameters $[2,7,8]$ and it's extremely difficult to get material with even structure and constant mechanical parameters [26].

\subsection{The influence of drying on biaxial deformation properties}

The influence of drying on the biaxial deformation of biofilm (Fig. 5) was investigated by punch loading experiment. In punch experiment (Table 3) samples dried at $75{ }^{\circ} \mathrm{C}$ obtained the highest values of bursting strength (57.2 MPa) as the lowest value of strength was observed for samples BC25 (37.1 MPa). Punch displacement changes were insignificant for all tested samples (from $21.7 \mathrm{~mm}$ for sample BC25 to $17.8 \mathrm{~mm}$ for sample BC75).

Table 3. Bursting properties of $\mathrm{BC}$ biofilm

\begin{tabular}{|l|c|c|c|}
\hline & $\begin{array}{c}\mathrm{BC} 25 \\
(\mathrm{CV}, \%)\end{array}$ & $\begin{array}{c}\mathrm{BC} 50 \\
(\mathrm{CV}, \%)\end{array}$ & $\begin{array}{c}\mathrm{BC} 75 \\
(\mathrm{CV}, \%)\end{array}$ \\
\hline Punch load $F_{p}, \mathrm{~N}$ & $\begin{array}{c}370.7 \\
(13.28)\end{array}$ & $\begin{array}{c}516.8 \\
(43.56)\end{array}$ & $\begin{array}{c}571.9 \\
(38.9)\end{array}$ \\
\hline Bursting strength $\sigma, \mathrm{MPa}$ & 37.1 & 52.8 & 57.2 \\
\hline Punch displacement $X, \mathrm{~mm}$ & $\begin{array}{c}21.7 \\
(22.89)\end{array}$ & $\begin{array}{c}20.9 \\
(23.51\end{array}$ & $\begin{array}{c}17.8 \\
(15.68)\end{array}$ \\
\hline
\end{tabular}

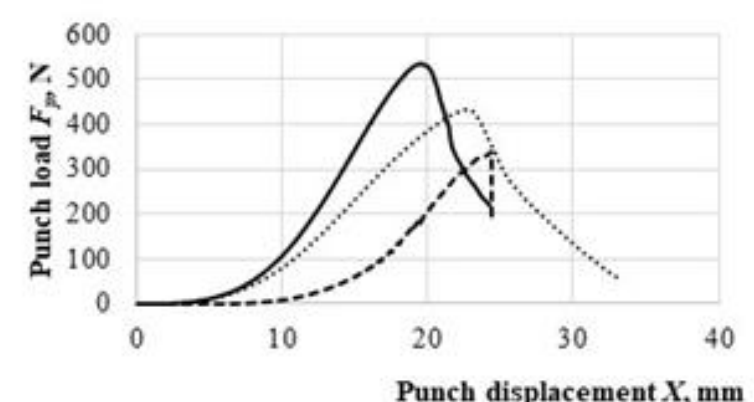

$-\mathrm{BP} 25$

BP50 BP75

Fig. 5. Typical punch load - displacement curves obtained for BC samples

The estimated parameters showed biaxial behaviour of investigated BC similar to natural leather. The value of BC bursting strength was higher than natural leather [27] as $\mathrm{BC}$ punch displacement values were also higher [28].

In bursting deformation process a shell of complicated shape with two zones is formed [29]. The punch contact top zone and thinned neck zone of a biomaterial shell differ in length and breaking nature. In Fig. 6 presented samples of BC biofilm after a ball burst test.

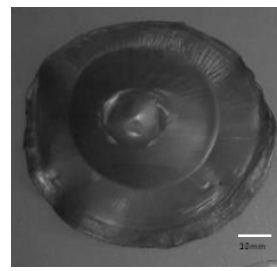

a

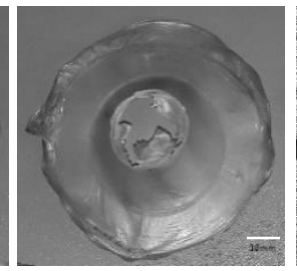

b

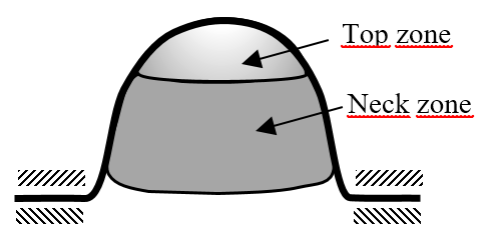

d

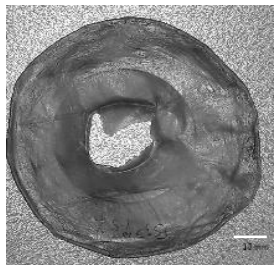

c
Fig. 6. $\mathrm{BC}$ biofilm samples after ball burst test: a-dried at $25^{\circ} \mathrm{C}$; b-dried at $50{ }^{\circ} \mathrm{C} ; \mathrm{c}-$ dried at $75{ }^{\circ} \mathrm{C} ; \mathrm{d}$ - shell scheme

Samples dried at $25{ }^{\circ} \mathrm{C}$ have longer neck and rounded up cap, which was smaller than for samples dried at higher temperatures. Shells of samples dried at $50{ }^{\circ} \mathrm{C}$ and $75^{\circ} \mathrm{C}$ temperatures have shorter neck zone and wider cap zone with a crack in the centre. It shows that dried at a higher 
temperature $\mathrm{BC}$ biofilm loses its elasticity and exposed to the biaxial deformations mainly deforms and ruptures in the contact zone (punch contact top zone) when critical deformations are exceeded.

\section{CONCLUSIONS}

The change in the sample size (thickness and planar dimensions) during dried $\mathrm{BC}$ biomaterial production is important for the material application. It is estimated that during drying procedure the biofilm loses up to $92 \%$ of the weight and up to $87 \%$ of the thickness therefore planar dimensions of material specimen varied insignificantly (up to $0.04 \%$ ). The appropriate procedure of biomaterial preparation (drying conditions) can prevent a surface shrinkage due to the rapid moisture evaporation.

$\mathrm{BC}$ biomaterial possesses useful mechanical properties, therefore due to the natural fermentation process, it is difficult to ensure even structure and constant mechanical parameters of biomaterial. The study proved the influence of drying temperature on the tensile and bursting behaviour of material.

The highest tensile strength $(27.91 \mathrm{MPa})$ is recorded for the samples dried at temperature of $25^{\circ} \mathrm{C}$ when the moisture out of the BC film is removed gradually. Dried at a higher temperature material loses its strength therefore elasticity for sample dried at $25^{\circ} \mathrm{C}$ and $50{ }^{\circ} \mathrm{C}$ remains similar. In the biaxial punch loading of $\mathrm{BC}$ biofilm, a shell of complicated shape is formed. Shell zones and rupture character differ according to sample preparation procedure (drying temperature). The maximum bursting strength (57.2 MPa) is recorded for samples dried at $75{ }^{\circ} \mathrm{C}$ when punch displacement changes is insignificant for all tested samples (from $17.8 \mathrm{~mm}$ to $21.7 \mathrm{~mm}$ ).

\section{REFERENCES}

1. Nechyporchuk, O., Belgacem, M.N., Bras, J. Production of Cellulose Nanofibrils: A Review of Recent Advances Industrial Crops and Products 93 2016: pp. 2-25. https://doi.org/10.1016/j.indcrop.2016.02.016

2. Yoshinaga, F., Tonouchi, N., Watanabe, K. Research Progress in Production of Bacterial Cellulose by Aeration and Agitation Culture and its Application as a new Industrial Material Bioscience, Biotechnology and Biochemistry 61 (2) 1997: pp. 219-224. https://doi.org/10.1271/bbb.61.219

3. Fontana, J.D., Koop, H.S., Tiboni, M., Grzybowski, A., Pereira, A., Kruger, C.D., Silva, M.G.R., Wielevski, L.P. New Insights on Bacterial Cellulose Food Biosynthesis 2017: pp. $213-249$.

https://doi.org/10.1016/B978-0-12-811372-1.00007-5

4. Shah, J., Brown, M.R. Towards Electronic Paper Displays Made from Microbial Cellulose Applied Microbiology and Biotechnology 4 2005: pp. 352-355. https://doi.org/10.1007/s00253-004-1756-6

5. Sim, K., Youn, H.J. Preparation of Porous Sheets with High Mechanical Strength by the Addition of Cellulose Nanofibrils Fibers and Polymers $16(2)$ 2015: pp. $294-301$.

https://doi.org/10.1007/s10570-016-0865-6
6. Hu, W., Yang, J., Wang, H. Functionalized Bacterial Cellulose Derivatives and Nanocomposites Carbohydrate Polymers 101 2014: pp. $1043-1060$. https://doi.org/10.1016/j.carbpol.2013.09.102

7. Goh, W.N., Rosma, A., Kaur, B., $\quad$ Fazilah, A., Karim, A.A., Bhat, R. Fermentation of Black Tea Broth (Kombucha): I. Effects of Sucrose Concentration and Fermentation Time on the Yield of Microbial Cellulose International Food Research Journal 19 (1) 2012: pp. $109-117$. https://doi.org/10.1016/j.foodchem.2007.11.069

8. Dufresne, C., Farnworth, E. Tea, Kombucha, and Health: A Review Food Research Journal 33 (6) 2000: pp. 409-421. https://doi.org/10.1016/S0963-9969(00)00067-3

9. Dima, S.O., Panaitescu, D.M., Orban, C., Ghiurea, M., Doncea, S.M., $\quad$ Fierascu, R.C., $\quad$ Nistor, C.L., Alexandrescu, E., Nicola, C.A., Trica, B., Moraru, A., Oancea, F. Bacterial Nanocellulose from Side-Strems of Kombuch Beverages Production: Preparation and Physical-Chemical Properties Polymers 9 (8) 2017: pp. 236-245. https://doi.org/10.3390/polym9080374

10. Chan, C.K., Shin, J., Jiang, S.X.K. Development of Tailor-Shaped Bacterial Cellulose Textile Cultivation Techniques for Zero-Waste Design Clothing and Textiles Research Journal 36 (1) 2018: pp. 1940-2473. https://doi.org/10.1177/0887302X17737177

11. Fu, L., Zhang, J., Yang, G. Present Status and Applications of Bacterial Cellulose-Based Material for Skin Tissue Repair Carbohydrate Polymers $92(2)$ 2013: pp. $1432-1442$. https://doi.org/10.1016/j.carbpol.2012.10.071

12. Pa'e, N., Hamid, N.I.A., Kharuddin, N., Zahan, K.A., Seng, K.F., Siddique, B.M., Muhamad, I.I. Effect of Different Drying Methods on the Morphology, Crystallinity, Swelling Ability and Tensile Properties of Nata de Coco Sains Malaysiana 43 (5) 2014: pp. $767-773$.

https://doi.org/10.4028/www.scientific.net/AMR.239 242.2667

13. Mohmmadkazemi, F., Azin, M., Ahori, A. Production of Bacterial Cellulose Using Different Carbon Sources and Culture Media Journal of Carbohydrate Polymers 117 (6) 2015: pp. 518-523. https://doi.org/10.1016/j.carbpol.2014.10.008

14. Mikkelsen, D., $\quad$ Flanagan, B.M., $\quad$ Dykes, G.A., Gidley, M.J. Influence of Different Carbon Sources on Bacterial Cellulose Production by Gluconacetobacter Xylinus Strain ATCC 53524 Journal of Applied Microbiology 107 (2) 2009: pp. 576-583. https://doi.org/10.1111/j.1365-2672.2009.04226.x

15. Basak, A.K. Drying Characteristics of Bacterial Cellulose Produced from Fermentation of Black Tea by Symbiotic Colony of Yeast and Bacteria International Journal of Science and Research 4 (6) 2013: pp. 1144-1147. https://doi.org/10.13140/RG.2.2.34100.55684

16. Zeng, M., Laromaine, A., Roig, A. Bacterial Cellulose Films: Influence of Bacterial Strain and Drying Route on Film Properties Cellulose 21 (6) 2014: pp. 4455-4469. https://doi.org/10.1007/s10570-014-0408-y

17. Peng, Y., Gardner, J.D., Han, Y. Drying Cellulose Nanofibrils: in Search of a Suitable Method Cellulose 19 (1) 2011: pp. $91-102$. https://doi.org/10.1007/s10570-011-9630-z 
18. Feng, X., Ullah, N., Wang, X., Sun, X., Li, C., Bai, Y., Chen, L., Li, Z. Characterization of Bacterial Cellulose by Gluconacetobacter Hansenii CGMCC 3917 Food Science 80 (10) 2015: pp. 2217-2227.

https://doi.org/10.1111/1750-3841.13010

19. Ul-Islam, M., Khattak, W.A., Kang, M., Kim, A.M., Khan, T., Park, J.K. Effect of Post-Synthetic Processing Conditions on Structural Variations and Applications of Bacterial Cellulose Cellulose $20(1)$ 2013: pp. $252-263$. https://doi.org/10.1007/s10570-012-9799-9

20. Costa, A.F.S., $\quad$ Almeida, F.C.G., Vinhas, G.M., Sarubbo, L.A. Production of Bacterial Cellulose by Gluconacetobacter Hansenii Using Corn Steep Liquor as Nutrient Sources Microbiology 8 2017: pp. 2027. https://doi.org/10.3389/fmicb.2017.02027

21. Leather - Physical and Mechanical Test - Determination of Tensile Strength and Percentage Extension (ISO 3376:2011).

22. Textiles - Test Methods for Nonwovens - Part 5: Determination of resistance to Mechanical Penetration (Ball Burst Procedure) (ISO 9073-5:2008)

23. Indrianingsih, A.W., $\quad$ Rosyida, V.T., Jatmiko, T.H., Prasetyo, D.J., $\quad$ Poeloengasih, C.D., $\quad$ Apriyana, W., Nisa, K., Nurhayati, S., Darsih, C., Pratiwi, D., Suwanto, A., Ratih, D. Preliminary Study on Biosynthesis and Characterization of Bacterial Cellulose Films from Coconut Water INCONPROBIOS 2017 Conference Series: Earth an Environment Science 2017: pp. 101-109. https://doi.org/10.1088/1755-1315/101/1/012010
24. Huang, Y., Yang, J., Zhu, C., Sun, D. Recent Advances in Bacterial Cellulose Cellulose 21 (1) 2014. pp. 1-30. https://doi.org/10.1007/s10570-013-0088-z

25. Abral, H., Mahardika, M. Tensile Properties of Bacterial Cellulose Nanofibers - Polyester Composites IOP Conference Series: Materials Science and Engineering 2016: pp. $137-142$. https://doi.org/10.1088/1757-899x

26. Svensson, A., Nicklason, E., Harrah, T., Panilaitis, B., Kaplan, D.L., Brittberg, M., Gatenholm, P. Bacterial Cellulose as a Potential Scaffold for Tissue Engineering of Cartilage Biomaterials 26(4) 2005: pp. 419-431. https://doi.org/10.1016/j.biomaterials.2004.02.049

27. Nasr, A.I., Abdelsalam, M.M., Azzam, A.H. Effect of Tanning Method and Region on Physical and Chemical Properties of Barki Sheep Leather Egyptian Journal of Sheep and Goat Sciences 8(1) 2013: pp. 123-130. https://doi.org/10.12816/0005033

28. Saran, S., $\quad$ Mahajan, R.V., $\quad$ Kaushik, R., $\quad$ Isar, J., Saxena, R.K. Enzyme Mediated Beam House Operations of Leather Industry: A Needed Step Towards Greener Technology Journal of Cleaner Production 54 (1) 2013: pp. 315-322. https://doi.org/10.1016/j.jclepro.2013.04.017

29. Strazdiene, E., Daukantiene, V., Gutauskas, M. Friction Factor in Polyethylene Membrane Punch Deformation Polymer Testing 2001: pp. 191-197. https://doi.org/10.1016/S0142-9418(00)00022-2 